\title{
Perlindungan Hukum Terhadap Pengungsi Lintas Batas Negara Di Indonesia
}

\author{
Reinier Sukarnolus Dimitri Sitanala \\ Fakultas Hukum Universitas Pattimura, Ambon, Indonesia \\ E-mail: ongkysitanala30@gmail.com
}

\begin{abstract}
The protection of these cross-border refugees has already been regulated in international law, namely the Geneva Convention 1951 and the 1967 Protocol, but Indonesia is not a party to ratify the Convention. So far Indonesia has only dealt with the problem of cross-border refugees from a priesthood perspective. This resulted in many violated human rights. Indonesia as a transit country must cooperate with the country of origin, destination country and UNHCR to overcome and provide protection for cross-border refugees. The role taken is based on humanity's consideration of the suffering of cross-border refugees and the protection of Human Rights.
\end{abstract}

Keywords: Refugees, Legal Protection

\section{A. PENDAHULUAN.}

Era globalisasi, yang ada saat ini membuka peluang untuk terbukanya pasar bebas lintas antar Negara yang dibarengi dengan kemajuan teknoliogi yang kian meningkat. Halini yang membuat jualur lalu lintas antar negara begitu mudah diakses sehingga membuat batas-batas antar negara semakinsemu.Semakin terbuka lebarnya jalan lalu lintas antar Negara menyebabkan meninggkatnya pula mobilitas manusia antar satu Negara ke Negara lain. Fenomena ini sudah menjadi perhatian Negara-negara di dunia termasuk Indonesia.
Setiap Negara mempunyai kedaulatan untuk mengatur lalu lintas orang yang akan masuk dan keluar wilayah negaranya. Bahkan untuk berkunjung atau untuk berdiam sementara sesuai dengan ketentuan dan perundangundangan yang berlaku dimasing-masing Negara. ${ }^{1}$

Belakangan Indonesia telah menjadi Negara transit bagi para $\mathrm{p}$ [endatang illegal yang ingin menuju ke Negara Australia. Pendatang illegal adalah orang-orang asing yang masuk

\footnotetext{
${ }^{1}$ Jawahir Thontowi, Hukum Internasional di Indonesia, Madya Press. Yokyakarta, 2002, h.7
} 
dan keluar serta tinggal di suatru wilayah Negara tertentu tanpa disertai dengan kepemilikan dokumen keimigrasian yang lengkap dan $s \mathrm{sh}^{2}$. Pendatang ilegal ini diantaranya adalah pencari suaka dan pengungsi.

Pencari suaka sendiri mempunyai pengertianyang berbeda dengan pengungsi. Pencari suaka adalah orangorang yang terusir dari negaranya dan mencari suaka ke negara lain. ${ }^{3}$ Suaka adalah penganugerahan perlindungan dalam wilayah suatu suatu negara kepada orang-orang dari negara lain yang dating ke negara bersangkutan karena menghidari pengejaran atau bahaya besar. ${ }^{4}$ Sedang pengungsi adalah orang yang mencari tyempat yang aman ketika daerahnya ada bahaya yang mengancam. ${ }^{5}$ Pada dasarnya kedua hal tersebut hamper sama pengertiannya. Yakni mereka melakukan imigrasi karena negara asalnya bukan lagi negara yang dapat memberikan kehidupan yang layak bagi masa depan mereka. ${ }^{6}$ Hanya saja status pencari suaka merupakan salah satu fase sebelum mendapatkan keputusan tentang status pengungsinya. Jadi seorang pencari suaka belum tentu merupakan seorang pengungsi. Ia baru menjadi pengunsi setelah diakuinya statusnya oleh hokum internasiuonal maupun peraturan perundang-undangan dari negara yang mengaturnya. ${ }^{7}$

Kasus-kasus manusia perahu yang

2 John Hendri, Penanggulangan Imigran Gelap di Indonesia, Bina Cipta Perkasa, Jakarta, 1996. h. 33.

3 Wagiman. Hukum Pengungsi Internasional, Sinar Grafika,Jakarta, 2012, h. 3.

${ }^{4}$ Ajat Sudrajat Havid, Protecting RefugeeA Field Guide for NGO's; Pengungsi dalam Kerangka Kebijakan Keimigrasian Kini dan Yang Akan Datang. Tanpa Tahun dan halaman.

${ }^{5}$ Yus Badudu, , Kamus Bahasa Indonesia, Sinar Harapan, Jakarta, 1994, h. 54.

${ }^{6}$ Iman Santoso, Perspektif Imigrasi dalam Pembangunan Ekonomi dan KetahananNasional, Universitas Indonesia Press, Jakarta, 2005, h. 17.

7 Sulaiman Hamid, Lembaga Suaka dalam Hukum Internasional, Raja Grafindo Persada, Jakarta, 2002, h. 39. sering terdampar di perairan Indonesia sebelum sampai di negara tujuan frekuensinya semakin meningkat. Masalah pengungsi bukan hanya menyangkut satu atau dua negara, melainkan masalah satu kawasan sehingga memerlukan kerjasama antar negara asal, negara transit, dan negara tujuan. Oleh karena itu diperlukan kerangka kerja sama antar negara asal, negara transit dan negara tujuan maupun peratuaran yang dapat menjadi acuan bagi penyelesaian masalah yang tidak bersifat kasuistik saja.

Indonesia memiliki suatu system hokum nasional yang berdaulat penuh dan berlaku dalam yurisdiksi negara. (Syamin A.K.: hal. 317-322). Namun Indonesia dalam konteks relasi Internasional tidak dapat lepas dari hukum internasional. Hukum Internasioal yang dapat dipahami dan diterima sebagai keinginan dan komitmen masyarakat internasiuonal menjadi pertimbangan penting saat menyangkut hubungan dengan negara lain. Misalnya soal pencari suaka, pengungsi maupunimigran ilegal. Mengingat urgensinya bagi kepentingan negara maka hokum internasional tertentu harus diadopsi menjadi hokum nasional melalui suatu ratifikasi.

Dalam persoalan penggungsi, hukum internasional memiliki Konvensi Jenewa 1951 dan Protokol 1967, Indonesia bukan merupakan pihak yang ikut serta dan meratifikasi Konvensi dan Protokol tersebut.Oleh karena itu Indonesia tidak memiliki kewenangan untuk menentukan apakah seseorang atau sekelompok orang, yang meminta status pengunsi diakui sebagai pengungsi, kewenangan itu dilakukan oleh UNHCR berdasarkan mandat yang ditetapkan dalam statutanya tahun 1950 di negaranegara yang bukan pihak penandatangan dalam Konvensi dan Protokol tersebut. Indonesia belum memiliki paying hokum untuk penangganan pengungsi yang masuk ke Indonesia. Indonesia hanya 
melakukan tindakan penam,pungan pada Rudenim (Undang-undang Nomor 6 Tahun 2011, Psl.81) 10, yang untuk selanjutnya dilakukan deportasi ke negara asalnya.

Hukum positif keimigrasian Indonesia tidak memuat ketentuan yang berlaku secara khusus (lex specialis) bagi pencari suaka dan pengungsi. Misalnya tidak ada prosedur administrasi keimigrasian secara spesifik.Ketiadaan instrument hukum operasional administrasi mengenai p[engungsi maupun pencari suaka ini telah menimbulkan kekosongan hukum ketika persoalan pengungsi dan pencari suaka ini hadir di Indonesia.

Pada level praktis ketiadaan instrument hukum ini telah menimbulkan kebingungan dan tumpah tindi kewenangan diantara institusi-institusi yang merasa berkepentingan untuk menangani persoalan-persoalan yang berkaitan dengan pengungsi dan pencari suaka di Indonesia. Dengan adanya kekosongan instrument hukum operasional, jelaslah bahwa instrument hokum pengungsi perlu dilembagakan dalam system hokum nasional Indonesia.

Mekanisme penanganan pengunsi di Indonesia sangat tergantung padas cara pandang negara ini pada pengungsi. Di Indonesia persoalan pengungsi masih diposisikan dari sudut pandang imigrasi sehingga semata-mata hanya dilihat dari perspektif keimigrasian. Konvensi tahun 1951 berikut Protokolnya tahun 1967 secara substansial melindungi Hak Asasi Manusia (HAM) pengungsi. Dengan demikian Konvensi tersebut dikategorikan sebagai jenis-jenis HAM yang perludilindungsi. Khususnya bagi pengungsi oleh klarena kondisi mereka yang memiliki jalur imigrasi akan melihat setiap permasalahan orang asing dari sudut keimigrasian. Orang asing yang masuk ke Indonesia tanpa surat perjalanan dianggap sebagai tindakan illegal. Padahal jika dirujuk pada kasuskasus konkret umumnya pengungsi atau pencari suaka tidak mungkin memiliki dokumen lengkap perjalanan.Sebab tidak mungkin mereka dalam keadaan terpaksa meninggalkan negaranya terlebih dahulu mengurus visa, passport atau surat-surat lainnya

Dari uraian Pada latar belakang tersebut, maka yang menjadi permasalahan dalam tulisan ini adalah : "Bagaimanakah Perlindungan Hukum dan Penanganannya Terhadap Pengungsi Lintas Batas Negara Di Indonesia”

\section{B. PEMBAHASAN}

\section{Indonesia Sebagai Negara Transit Bagi Pengungsi Lintas Batas}

Indonesia memiliki masalah tersendiri berkaitan dengan pengurusan imigrasi. Sebagai negara transit maupun negara tujuan, Indonesia tidak dapat lepas tangan terhadap penganggulangan merekayang masuk ke Indonesia. Untuk hal tersebut diperlukan suatu pengaturan hukum mengenai penanggulangan maupun perlindungan terhadap pengungsi secara terintegrasi mengingat permasalahan ini telah menjadi salah satu isu penting bagi negera ini.

Secara geografis letak Indonesia sangat strategis sebagai negara transit bagi para pengungsi lintas batas negara. Hal tersebut terjadi karena Indonesia memiliki pelabuhan kapal laut serta berbatasan dengan nnegara lain,terutama berbatasan dengan Kalimantan Barat dengan Sabah Malaysia, Australia di bagian selatan, juga bagian timuir dengan Timor Leste. Terdapat 79 ( tuju puluh Sembilan) pintu perbatasan legal di Indonesia di luar jalur-jalur imigrasi.Dikenal dua rute yaitu jalur barat danjalur timur. Jalur barat melalui Medan, Jambi, Batam dan Lampung. Jalur timur melalui Bau-Bau Sulawesi Tenggara.

Selain itu berdasarkan kasus-kasus yang tejadi terdapat dua jalur para pengungsi untuk menuju Australia. 
Pertama, setelah sampai di Jakarta mereka kemudian menuju Bogor untuk masuk di tempat penampungan.Dari Bogor mereka menempuh jalur darat menuju pelabuhan Bakauheni Lampung. Dari Lampung mereka menggunakan jalur laut menuju Pulau Chrismast Australia. Kedua, menggunakan jalur kawasan timur melalui Pulau Rote di Nusa Tenggara Timur.

Pada akhir Januari 2012, menurut data UNHCR terdapat 3275 pencari suaka dan 1052 pengungsi yang terdaftar di UNHCR Jakarta. Selama Januari terdapat 315 orang terdaftar dengan jumlah pencari suaka terbesar berasal dari Afganistan (66,6\%), diikuti dengan Iran $(9,8 \%)$,dan Somalia $(6,7 \%)$.(Diakses dari ICJR.or.id) 07 Sep 2013).1. Indonesia sendiri masih merupakan negara transit dan hingga saat ini belum menjadi negara pihak dalam Konvensi Pengungsi 1951 dan Protokol Opsional 1967.

Banyaknya pengungsi yang masuk di Indonesia sangat logis, karena lokasi geografis Indonesia yang sangat strategis. Para pengungsi tersebut sebagian besarnya hendak menuju Australia, Canada, Amerika Serikat, Selaindia Baru, dan Norwegia. Motif terbesar dari para pengungsi tersebut adalah menghidar presekusi,atau menghindari perang yang terjadi dinegaranya.

Karena system hukum di Indonesia belum meratifikasi Konvensi Pengungsi dan Protokol, maka Undang-Undang No.6 Tahun 2011 tentang Keimigrasian, masih mengkategorikan pengungsi sebagai imigran illegal atau imigran yang memasuki wilayah Indonesia tanpa dokumen keimigrasian yang resmi. Untuk itu para pengungsi yang masuk ke wilayah Indonesia selalu dikenakan tindakan keimigrasian dalam bentuk penahanan selama jangka waktu maksimum 10 tahun di rumah Detensi imigrasi yang tersebar di 13 lokasi di seluruh Indonesia.

Sebagai negara yang telah merdeka sejak tahun 1945 dan menjadi anggota
PBB selama 57 tahun,seyogianya Indonesia segera meratifikasi Konvensi PBB tahun 1951 tentang Pengungsi. Pembukaan Undang-Undang Dasar Republik Indonesia 1945, telah menyatakan niatnya untuk melaksanakan ketertiban dunia berdasarkan kemerdekaan, perdamaian abadi, dan keadilan soaial. Kedudukan Indonesia dalam tataran internasional seharusnya menjadi pendorong aksesinya pada instrumen-instrume internasional mengenai Hak Asasi Manusia yang belum diratifikasi, termasuk Konvensi tahun 1951 berikut Protokol tahun1967 yang telah diratifikasi oleh 140 negara. Indonesia pernah menjadi tuan rumah sekaligus salah satu pemrakarsa Konfensi Asia Afrika 1955 di Bandung. Pada keputusan finalnya menyatakan dukungan penuh terhadap prinsip-prinsip fundamental Hak Asasi Manusia sebagaimana tercantum dalam Piagam PBB dan mencatat Deklarasi Universal Hak Asasi Manusia (DUHAM) 1948 sebagai standar pencapaian bersama bagi semua rakyat dan bangsa.

Sejak tahun 1975 Indonesia bekerja sama dengan UNHCR dan komunitas internasional bagi upaya penyelesaian masalah pengungsi dari semenanjung Inodocina. Sejak tahun 1979 di Jakarta ada kantor cabang perwakilan UNHCR yang sekarang ini telah menjadi kantor regional yang wilayah kerjanya meliputi Brunei Darusalam, Filipina, Indonesia, Malasya dan Singapura.

Sebenarnya Indonesia pernah menjadi negara suaka bagi pengungsi, yakni pengungsi manusia perahu dari Vietnam yang kemudian ditampung dan diproses di pulau Galang sebelum direpatriasi atau dimukimkan di negara ke tiga. Ratifikasi Konvensi tahun 1951 dapat menjadi komitmen Indonesia di tataran Internasional untuk memajukan HAM. Mewujudkan solidaritas internasional dalam masalah kemanusiaan dan menyumbang upaya pembinaan perdamaian internasional. Hal 
demikian akan meningkatkan citra Indonesia. Jikan ikut meratifikasi Konvensi tahun 1951 tentang Pengungsi, Indonesia dapat berdaulat penuh melakukan penilaian untuk menentukan status pencari suaka sebagai pengungsi atau imigran gelap biasa. Ratifikasi dapat mencegah friksi dengan negara asal jika Indonesia harus menampung pencari suaka. Sebagai bagian dari komunitas internasional setiap beban menjadi tanggung jawab bersama dan selalu dibantu lewat UNHCR. Indonesia juga akan menjadi mudah untuk meminta bantuan internasional dalam menangani pengungsi.

Khusus di Indonesia, oleh karena Indonesia tidak termasuk dalam negara pihak pada Konvensi mengenai status Pengungsi tahun1951 dan Protokol 1967, maka Indonesia menyerahkan penanganan pengungsi pada UNHCR yang melakukan aktifitasnya berdasarkan mandat yang ditetapkan dalam statusnya tahun 1950 di negara-negara yang bukan pihak penandatanganan pada Konvensi tahun 1951 dan Protokol tahun 1967. Oleh karenanya Indonesia tidak memiliki wewenang untuk menentukan apakah seseorang atau sekelompok orang yang meminta status pengungsi diakui sebagai pengungsi. Kewwenangan tersebut dilakukan oleh UNHCR mengingat Indonesia bukan negara pihak Konvensi tahun 1951 dan Protokol tahun 1967. Indonesia tidak memiliki payung hukum untuk menangani pengungsi yang masuk ke Indonesia. Indonesia melakukan tindakan penampungan pada RUDENIM yang selanjutnya dilakukan deportasi ke negara asalnya.

\section{Kendala dan Tantangan Penanganan Pengungsi di Indonesia}

Indonesia memiliki suatu system hukum nasional yang berdaulat penuh dan berlaku dalam yurisdiksi seluruh negara.;Namun Indonesia dalam konteks relasi internasional tidak dapat lepas dari hokum internasional. Hukum internasional dapat dipahami dan diterima sebagai keinginan dan komitmen masyarakat internasional menjadi pertimbangan penting saat menyangkut hubungan dengan negara lain. Hukum Internasional tertentu mengingat urgensinya bagi kepentingan negara atau penghormatan terhadap masyarakat nasional dijadikan atau di adopsi menjadi hukum nasional melalui suatu ratifikasi.

Ratifikasi merupakan proses menjadikan suatu instrument internasional menjadi hukum nasional. Instrumen internasional secara resmi menjadi bagian dari hukum nasional,oleh karenanya ai mengikat secara hukum. Oleh karena itu, haruslah dibedakan antara instrument internasional dengan instrument nasional. Instrumen internasional hanya menyatakan keharusan serta cara menyatakan persetujuan suatu negara. Namun pada instrument nasional ditentukan otoritas mana yang berwenang untuk menentukan persetujuan pengikatan berikut prosedurnya. (Boer Mauna, 2005, hal. 115-116) 11.

Terkait dengan konteks Indonesia, dirumuskannya ketentuan hukum atau perundang-undangan nasional mengenai pengungsi juga didasarkan pada standarstandar internasional. Hal ini merupakan kunci yang melengkapi lembaga suaka, membuat perlindungan lebih efektif, dan memberikan landasan bagi pencarian solusi bagi persoalan yang dihadapi oleh pengungsi. Inkorporasi hukum internasional ke dalam hukum nasional sanghat penting dan perlu diulakukan di bidang-bidang yang tidak diatur oleh instrument internasional hukum pengungsi, seperti hal-hal yang bersifat prosedural tentang proses penentuan status pengungsi.

Secara de jure Indonesia tidak terikat ketentuan-ketentuan yang terdapat di dalam Konvensi tersebut, namun demikian harus kita sadari semua bahwa 
di dalam masyarakat internasional dan pergaulan internasional di mana negara Indonesia berada di dalamnya, ada kaidah-kaidah atau norma-norma internasional baik tertulis maupun tidak tertulis yang harus kita taati. Bahwa walaupun bukan negara penandatangan secara de fakto Indonesia masih harus tunduk kepada norma serta kaidah yang ada di dalam Konvensi tersebut,harus diingat bahwa pemerintah kita telah meratifikasi Undang-Undang No. 39 tentang Hak Asasi Manusia dimana di dalamnya juga mengatur tentang hak-hak seorang pencari suaka dan pengungsi dalam pasal 14.

Konteks normative di Indonesia terkait dengan suaka telah ditegaskan dalam Konstitusi Negara Republik Indonesia,Undang-Undang Dasar 1945, Amandemen ke-4 tahun 2000 pada Pasal 28G ayat (2) menyatakan:"Setiap orang berhak untuk bebas dari penyiksaan atau perlakuan yang merendahkan derajat martabat manusia danmemperoleh suaka politik dari negara lain".Dengan adanya rumusan tentang hak untuk memperoleh suaka didalam Undang-Undang Dasar 1945, berarti hak untukmencari suaka merupakan ahakyang dilembagakan dandijamin secara konstitusional. Di samping Undang-UndangDasar 1945, penegasan tentangt hak untuk memperoleh suaka itu juga ditegaskan dalamUndang-Undang No.39 tahun 1999 tentang Hak Asasi Manusia. DalamPasal 29 Undang-Undang No. 39 Tahun 1999 disebutkan (1) Setiap orangt berhak mencari suaka untuk memperoleh perlindungan politiki di negara lain. (2) Hak sebagaimana dimaksud dalam ayat (1) tidak berlaku bagi ,mereka yang melakukan kejahatan nonj-politik atau perbuatan yang bertentangan dengan tujuan dan prinsip Perserikatan BangsaBangsa (PBB).

Undang-Undang No. 37 Tahuin 1999 tentang Hubungan Luar Negeri, pada Pasal 25 menyebutkan; "Kewenangan memberikan suaka kepada orang asing berada ditangan Presiden dengan memperhatikan Pertimbangan Menteri "Pasal 26 Undang-undang No. 37 Tahun 1999 yang menyebutkan “ Pemberian suaka kepada orang asing dilaksanakan sesuai dengan peraturan perundang-undangan nasional serta dengan memperhatikan hukum, kebiasaan dan praktek Internasional.

Ayat (1) menyebutkan" Permintaan ekstradisi ditolak, jika terdapat sangkaan yang cukup kuat, bahwa yang dimintakan ekstradisinya akan dituntut, dipidana, atau dikenakan tindakan lain karena alas an yang bertalian dengan agamanya, keyakinan politik atau kewarganegaraannya, atau karena ia termasuk suatu suku bangsa atau golongan penduduk tertentu".

Meskipun terdapat rumusan normativ dalam konstitusi mapun peraturan perundang-undangan lainnya tentang hak memperoleh suaka politik di Indonesia, hingga saat ini implementasi tentang hak pencari suakaini belum ada aturan operasionalnya yang jelas. Oleh karena itu, pengungsi atau pencari suaka yang masuk ke wilayah hokum Indonesia berada dalam situasi yang rumit. Tidak adanya legislasi hokum pengungsi di Indonesia merupakan kendala bagi operasional terkait dengan masuknya pencari suaka dan pengungsi ke wilayah Indonesia. Situasi seperti ini terjadi karena, hingga saat ini instrument hukum internasional terkait pengungsi belum diinkorporasikan ke dalam system hukum nasional. Indonesia sampai saat ini tidak memiliki perundang-undanagn yang secara khusus mengatur pencari suaka danpengungsi. Hingga saat ini Indonesia tidak menjadi pihak dan belum melakukan aksesi terhadap instrumen hukum internasional khususnya terhadap Konvensi Jenewa 1951 dan Protokol New York 1967 tentang Status Pengungsi. Ketiadaan instrument hukum operasional mengenai pengungsi dan pencari suaka ini telaha menimbulkan kekosongan hukum ketika persoalan pengungsi dan 
pencari suaka ini hadir di Indonesia. Dengan adanya kekosongan instrument hokum operasional untuk menjadi rujukan bagi institusi yang berkepentingan serta mengantisipasi persoalan pengungsi dan pencari suaka ini jelaslah bahwa instrument hukum pengungsi perlu dilembagakan dalam sistem hukum nasional Indonesia

\section{Mekanisme Pengungsi Lintas Batas di Indonesia}

Mekanisme penanganan pengungsi di Indonesia sangat tergantung pada cara pandang negara inipada pengungsi. Di Indonesia persoalan pengungsi masih diposisikan dari sudut pandang imigrasi sehingga pada umumnya ditangani melalui perspektif keimigrasian. Konvensi tahun 1951 berikut Protokolnya tahun 1967 secara substansialmelindungi hak asasi manusia pengungsi. Dengan demikianKonvensi tersebut dikategorikan sebagai jenis-jenis HAM yang perlu dilindngi, khususnya bagi pengungsi oleh karena kondisi mereka yang khusus.

Apabila terdapat kasus pengungsi maka mekanisme umum yang dilakukan adalah sebagai berikut :

1. Melaporkan

kepadakepolisianstempat

2. Kepolisisan setempat akan melapor ke MABES POLRI

3. MABES

POLRI

memberitahukanke Kementrian Luar Negeri

4. Kementrian Luar Negeri memberitahukan Perwakilan UNHCR di Indonesia

5. Petugas UNHCR akan melakukan wawancara dan menempatkan mereka di suatu tempat atas biaya UNHCR.

Pada Level kebijakan mekanisme untuk penanganan pengungsi dapat ditemukan dalam Peraturan Dirjend Imigrasi8 No.IMI-1489.UM.08.05 Tahun
2010 tentang Penanganan Imigrasi Ilegal, di mana setiap pengungsi yang masuk ke Indonesia akian dikenakan tindakan keimigrasian dalam bentuk penahanan sampai stasus pengungsinya ditetapkan olehUNHCR. Namun penetuan status oleh UNHCR dapat memakan waktu sangat lama.Hal ini berimbas pada munculnya pelanggaran HAM, karena pengungsi bukanlah pelaku kriminal, namun ditetapkan pada situasi yang mirip dengan penahanan. Tak heran jika banyak di antara pengungsi yang mengalami tekanan psikologis dan berkeinginan kuat untuk bunuh diri atau kabur dari rumah Detensi imigrasi tersebut. Pada 13 Nopember 2011, sebanyak 13 pengungsi dan pencari suaka kabur dari Rudenim Tanjungpinang. Seorang dari mereka gagal menembus kawat berduri Rudenim dan tewas, sementara seorang lainnya juga gagal kabur mengalami luka parah.

Idealnya penanganan orang-orang yang mkengklaimk bahwa pengungsi seharusnya di garis depan adalah bagian imigrasi. Akan tetapi TPI (Tempat Pelaporan Imigrasi) di Indonesia hanya ada di beberapa kota besar sehingga bila ditemukan kasus yang sama di tempattempat terpencil seperti di dekat pantai, maka pejabat daerah setempatlah yang terlebih dahulu ditemui yaitu Lurah. Apabila petugas kepolisian yang harus ditemui hanya karena segi kepraktisan semata, sebab Polsek bias ditemui di mana saja disbanding bagiann imigrasi.

Bagi negara seperti Indonesia yang memiliki jalur imigrasi akan melihat setiap permasalahan orang asing dari sudut keimigrasian. Apabila merujuk pada kasus-kasus konkret umumnya pengungsi atau pencari suaka tidak mungkin memiliki dokumen lengkap perjalanan. Sebab tidak mungkin mereka dalam keadaan terpaksa meninggalkan negaranya terlebih dahulu mengurus visa,paspor,atau surat-surat lainnya. 


\section{Upaya-upaya Pemerintah dalam} Memberikan Perlindungan Terhadap Pengungsi Lintas Babatas.

Hukum positif keimigrasian tidak memuat ketentuanyang berlaku secara khusus (lex specialis) bagi pencari suaka dan pengungsi. Misalnya tidak ada prosedur administrasi keimigrasian secara spesifik. Atas pertimbangan tersebut Pemerintah melalui Keimigrasian mencoba mengeluarkan suatu kebijakan tentang penanganan Imigrasi Ilegal yang berstatus pengungsi dan pencari suaka dengan mencoba berusaha untuk menselaraskan dan mengharmonisasikan antara menjaga kehormatan/kedaulatan negara dengan Law Enforcement Pemerintah RI yang dituangkan dalam Undang-Undang No. 6 Tahun 2011.Di dalam Undang-Undang No. 6 Tahun 2011, Indonesia secara implisit tidak mengatur tentang pencari suaka dan pengungsi, namun secara eksplisit sebenarnya telah masuk ke dalam kategori dalam Pasal 86 UndangUndang yang sama dikatakan bahwa Pemerintah tidak akan memberlakukan "Tindakan Administrasi Keimiugrasian" kepada korban perdaganagan orang dan penyelundupan manusia. Selanjutnya paqda Pasal 87 mengatur tentang penempatan merekabdi Rumah Detensi Imigrasi atau tempat penampungan yang telahditentukandanakan diperlakukan khusus.

Dengan memberikan penanganan kepada para korban tersebut yang notabene adalah berstatus pencari suaka dan pengungsi, maka sebenarnya Indonesia telah mengupayakan keselarasan antara Hukum Internasional yang mengatur tentang pengungsi yang berlaku Universal dengan Kedaulatan Negara sebagaimana telah diatur dalam Undang-Undang No. 6 Tahun 2011 tentang Keimigrasian. Penanganan Imigran Ilegal berstatus pencari suaka dan pengungsi itu sendiri pada saat ini hanya mengacu kepada Peraturan Dirjenjim No.IMI-1948.UMJ.08.05 Tahun 2010 antara lain bahwa Orang Asing yang masuk dantinggal tanpa dokumen adalah Imigran Ilegal. Penekanan terhadap Case Closed/rejected UNHCR akan segera dideportasi. Penekanan bahwa bagi pemegang surat UNHCR yang tidak berkedudukan di Indonesia akan terkenantindakan Keimigrasian. Imigrasillegal yang telah mendapatkanstatus pencari suaka atau pengungsi tyidak dipermasalahkan izin tinggal.

Dengan dasar Peraturan Dirjen di atas sudah jhelas sebenarnya arah dari tindakan Keimigrasianbyang harus dilakukan tyerhadap ImigranbIlegal berstatus Pencari suaka dang Pengungsi tersebut. Bahwa kenyataannya tidak akan semua dari para pemohon status refugees yang diterima dan disetujui untuk diberi status pengungsi internasional atau refugees oleh UNHCR dengan alasan atau pun tolok ukur yang hanya diketahui oleh pihak UNHCR sendiri.

Mereka yang telah menerima penolakan status, tetap memperoleh kesempatan untuk banding selama 3 kali sebelum dinyatakan kasus mereka ditutup (Case Closed) data sudah tidak ada kemungkinan lagi untuk diberikan status dan diminta secvara sukarela untuk pulang ke negara asalnya difasilitasi oleh IOM (International Organization for Migration). Namun pada kenyataannya dilapangan bahwa sebagaian besar dari mereka akan menolak untuk dipulangkan dengan suka rela oleh pihak imigrasi dengan bantuan IOM. Hal ini menimbulkan kesulitan sendiri pada saat akan mengusahakan pemulangan paksa/deportasi karena pihakIOM tidak dapat menggunakan dananya manakala itu suatu upaya paksa. IOM hanya akan mengeluarkan bantuan danadengan program AVR (Assisted Voluntary Return). Sedangkan dana deportasi untuk Imigran Ilegal tidak akan mencukupi untuk pemulangan keseluruhan kasus- 
kasus Case Closed ini.

Kemudian dalam penanganan kasus Imigran Ilegal yang telah mendapatkan status pencari suaka (Asylumk Seekers) dan pengungsi (Refugees), sebagaimana telah tercantum pada peraturan Dirjen di atas bahwa Imigran Ilegal yang telah mempunyai status-status tersebut ada kemungkinan untuk tidak dipermasalahkan izintinggal, juga menjadi persoalan sendiri bagi Pemerintah Indonesia.

Sudah saatnya perlindungan terhadap pengungsi yang masuk ke Indonesia ditangani secara terintegrasi karena kasusnya sudah meluas dan menjadi isu penting bagi dunia internasional maupun Indonesia sendiri.

\section{PE N U T U P}

Berdasarkan pada apa yang telah diuraikan di atas, maka penulis dapat menarik kesimpulan sebagai berikut :

1. Indonesia secara tertulis tidak memiliki tanggung jawab langsung terhadap pengungsi-pengungsi asing, ini karena pertimbangan keamanan nasional dan memprioritaskan kesejahteraan social masyarakat Indonesia. Indonesia termasuk negara yang tidak menandatangani Konvensi 1951 yang mengatur tentang status pengungsi. Situasi seperti ini membuat pengungsi atau pencari suaka berada pada kondisi yang rumit. Tidak adanya legislasi hukum tentang pengungsi di Indonesia merupakan kendala yang besar bagi penanganan pengungsi. Kendala ini disiasati Indonesia dengan melakukan kerjasama dengan UNHCR maupun IOM. Ketiadaan instrument hokum yang terintegrasi khusus dengan lembaga-lembaga Internasional mengakibatkan penylesaian permasalahan mengenai pengungsi ini terkatung-katung dan memakan waktu yang lama sehingga banyak pengungsi yang hak-hak asasinya dilanggar.

2. Selama ini penanganan terhadap masalah pengungsi lintas batas di Indonesia diselesaikan dengan tindakan keimigrasian semata. Hal ini disebabkan oleh tidak dicantumkannya peraturan terkait penaganan pengungsi secara khusus dan belum diratifikasinya Konvensi Jenewa 1951 dan Protokol Tambahan 1967. Pengungsi yang masuk kewilyah Indonesia diperlakukan dengan mekanisme selayaknya imiran legal antara lain ditampung di rumah Detensi migrasi (RUDENIM) dan kemudian dideportasi. Proses deportasi ini pun memiliki kendala di antaranya; dana yang disediakan oleh International Organization of Migration (IOM) tidak mencukupi untuk memulangkan seluruh pengungsi yang Case Closed dan negara-negara penerima seperti negara -negara Eropa, Australia, dan Amerika memperketat dan mempersulit penerimaan pengungsi yang tidak mempunyai skill. Pemerintah Indonesia melalui institusi-institusi yang berkaitan (Kementrian Luar Negeri, Sosial, POLRI, Imigrasi dan Rutan) harus memberikan kejelasan bagi penanganan pengungsi asing di Indonesia. Usaha Pemerintah dalam pembentukan tim Penanganan Penyelundupan Manusia, Pengungsi, dan Pencari Suaka atau P2MP2S adalah benar namun tidak cukup untuk menyelesaikan masalah pengungsi asing di Indonesia yang kedepannya belum jelas

\section{DAFTAR PUSTAKA}

Badudu, Yus, Kamus Bahasa Indonesia, Sinar Harapan, Jakarta, 1994.

Hamid, Sulaiman, Lembaga Suaka dalam 
Hukum Internasional, PT Raja Grafindo Persada, Jakarta, 2002.

Hendri, John, Penanggulangan Imigran Gelap di Indonesia, Bina Cipta Perkasa, Jakarta, 1996.

Iman Santoso, Perspektif Imigrasi dalam Pembangunan Ekonomi dan KetahananNasional, Universitas Indonesia Press, Jakarta, 2005.

Mauna Boer, Hukum Internasional : Pengertian Peranan dan Fungsi dalam Era Dinamika Global, Alumni Bandung, 2005.

Sudrajat Havid, Ajat, Protecting RefugeeA Field Guide for NGO's; Pengungsi dalam Kerangka Kebijakan Keimigrasian Kini dan Yang Akan Datang.

Thontowi, Jawahir. Hukum Internasional di Indonesia, Madya Press. Yokyakarta, 2002.

Wagiman. Hukum Pengungsi Internasional, Sinar Grafika, Jakarta, 2012.

Undang-Undang Nomor 6 Tahun 2011 tentang Keimigrasian 